\title{
Myoinositol augments insulin release from perfused rat pancreas
}

\author{
T. Szkudelski, Jolanta Chichłowska and A. Kliber \\ Department of Animal Physiology and Biochemistry, \\ Agriculture University \\ Wolyńska 35, 60-637 Poznań, Poland
}

(Received 6 August 1998; accepted 19 November 1998)

\begin{abstract}
To test the direct influence of myoinositol on insulin release, rat pancreases were perfused with a medium containing glucose $(6.6 \mathrm{mmol} / \mathrm{L})$ or glucose with myoinositol at concentrations of 0.15 , 1.55 or $15.5 \mathrm{mmol} / \mathrm{L}$. Myoinositol at the lowest concentration was without effect. At concentrations of 1.55 and $15.5 \mathrm{mmol} / \mathrm{L}$ inositol significantly augmented insulin secretion; the total amount of insulin relcased during perfusions $(30 \mathrm{~min}$ ) with this compound was 508 and $478 \mu \mathrm{U}$, respectively vs $353 \mu \mathrm{U}$ secreted during the same time of perfusion without inositol. It seems quite possible that inositol may augment insulin secretion by formation of ATP, inositol phospholipids or inositol hexaphosphate.
\end{abstract}

KEY WORDS: inositol, insulin, secretion, pancreas, perfusion, rat

\section{INTRODUCTION}

Inositol is the precursor of the inositol phospholipids, which after cleavage by phospholipase $\mathrm{C}$, generate ubiquitous second messengers i.e. 1,4,5-inositol triphosphate and diacylglycerol. Considerable amounts of inositol may reach the cells from the digestive tract. An important source of this compound is total dephosphorylation of phytic acid (inositol hexaphosphate) which takes place in the digestive tract (Sakamoto et al., 1993). Since phytic acid is present in large quantities in the seeds of many plants as well as in seed-derived products (Reddy et al., 1982), consumption of many kinds of food is an important source of inositol for 
the organism. It is known that the presence of inositol (or phytic acid) in the consumed food may change certain metabolic processes. One of the effects of inositol is lowering liver triglycerides (Andersen and Holub, 1980). However, the influence of exogenous inositol on the organism is not well documented.

There are numerous compounds in food that after absorption from the digestive tract, reach the pancreas and may influence insulin secretion. They may exhibit stimulatory or inhibitory action. Inositol is one of the compounds absorbed from the digestive tract, but its effect on the endocrine function of the pancreas is poorly characterized.

The aim of this work was to ascertain the direct effect of inositol on insulin secretion from in situ perfused rat pancreas.

\section{MATERIAL AND METHODS}

In the experiments male Wistar rats of $200 \pm 10 \mathrm{~g}$ body weight were used. Rats were kept in standard conditions and prior to the experiment the animals were fasted for 14-16 h. Experiments were carried out according to the method of in situ pancreas perfusion described by Penhos et al. (1969). The basic perfusion medium was Krebs-Ringer buffer containing $0.2 \%$ bovine serum albumin (fraction $\mathrm{V}$ ) and $4 \%$ dextran $T 70000$. After surgical preparation of rats performed under general ether anaesthesia, pancreases were stabilized for thirty min using this medium. The temperature of the medium was $37 \pm 0.5^{\circ} \mathrm{C}$ and constant $\mathrm{pH}$ was maintained at $7.4 \pm 0.05$ by blowing the medium through with carbogen. After the stabilization period, the perfusions proper began. In the control experiments, pancreases were treated for $46 \mathrm{~min}$ with the medium containing glucose $(\mathrm{C})$. In the proper design after 16 min of perfusion with the medium containing glucose, between 16 and 46 min of experiments, pancreases were perfused with a medium containing glucose and myoinositol $(\mathrm{C}+\mathrm{MI})$ at a concentration of $0.15,1.55$ or $15.5 \mathrm{mmol} / \mathrm{L}$. The concentration of glucose was $6.6 \mathrm{mmol} / \mathrm{L}$. In order to determine insulin, the perfusion medium, flowing out of the pancreas by a cannula inserted in the portal vein, was collected into separate test-tubes in two min intervals during perfusion. Insulin was assayed using a radioimmunological RIA-INS test (Świerk, Poland). The mean concentrations of this hormone in perfusates obtained in two-min intervals were compared between control and appropriate min of perfusion with myoinositol. Myoinositol and bovine serum albumin were from Sigma and all other reagents were of the highest purity commercially available.

The results were statistically evaluated with paired comparisons $t$-Student test $(\mathrm{P} \leq 0.05)$. 


\section{RESULTS}

The effect of glucose on insulin release is presented on Figure 1, while Figure 2 shows the influence of myoinositol at the concentrations of $0.15,1.55$ and 15.5 $\mathrm{mmol} / \mathrm{L}$, respectively, on insulin release.

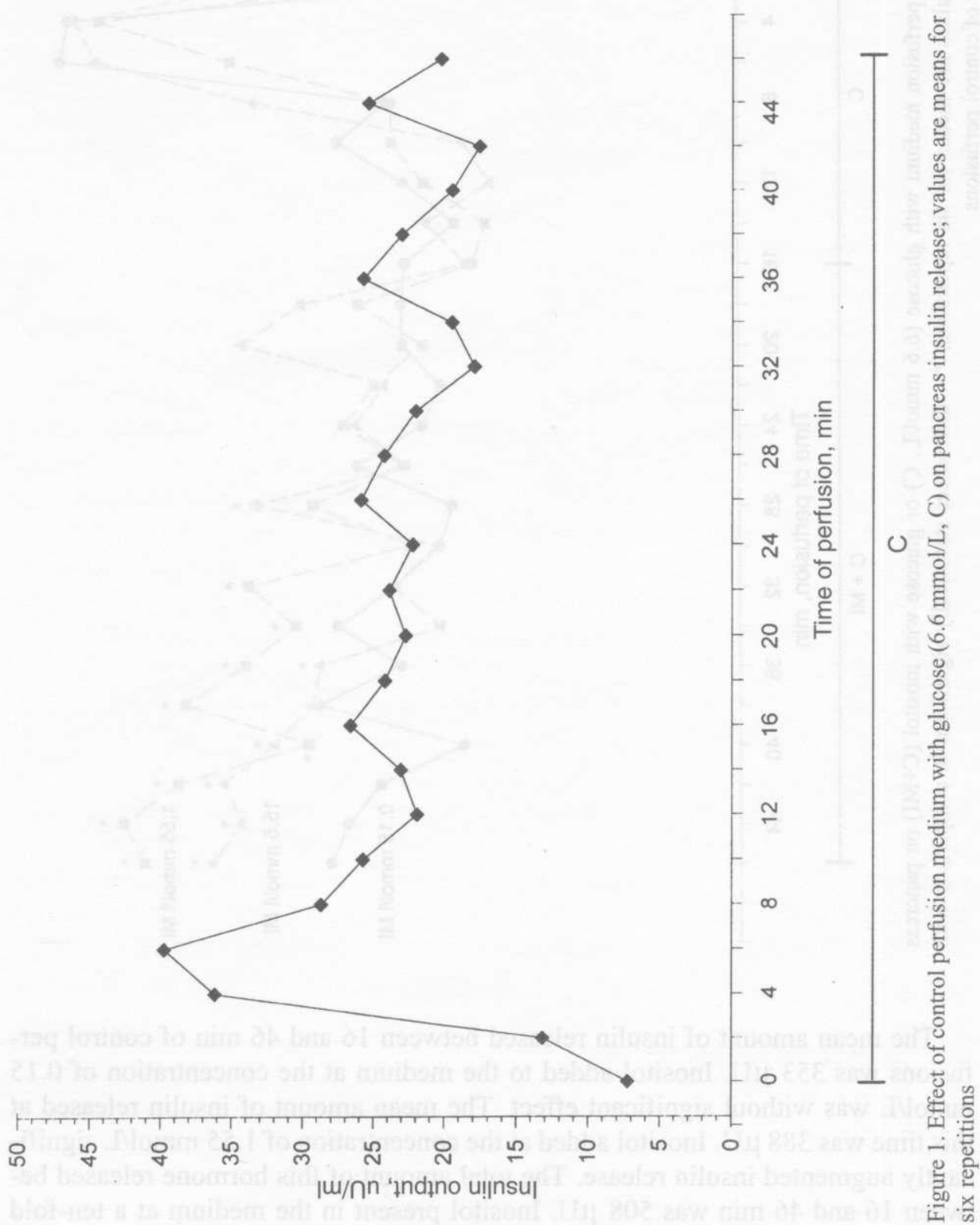




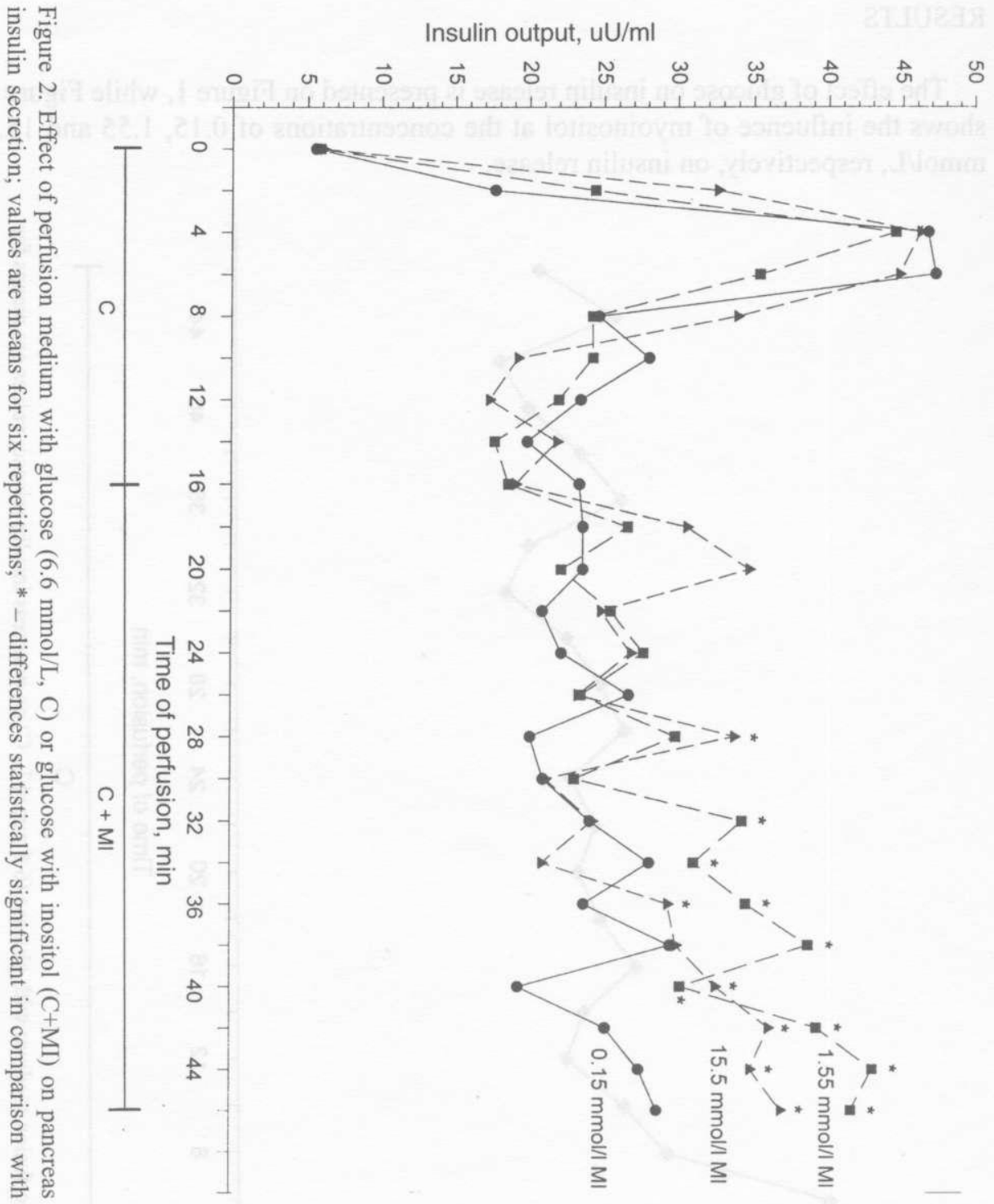

The mean amount of insulin released between 16 and 46 min of control perfusions was $353 \mu \mathrm{U}$. Inositol added to the medium at the concentration of 0.15 $\mathrm{mmol} / \mathrm{L}$ was without significant effect. The mean amount of insulin released at this time was $388 \mu \mathrm{U}$. Inositol added at the concentration of $1.55 \mathrm{mmol} / \mathrm{L}$ significantly augmented insulin release. The total amount of this hormone released between 16 and $46 \mathrm{~min}$ was $508 \mu \mathrm{U}$. Inositol present in the medium at a ten-fold 
higher concentration $(15.5 \mathrm{mmol} / \mathrm{L})$ had a similar effect. The amount of insulin released between 16 and 46 min of perfusion with this concentration of inositol was $478 \mu \mathrm{U}$.

\section{DISCUSSION}

In the performed experiments it was clearly demonstrated that myoinositol present in the perfusion medium at concentrations of 1.55 or $15.5 \mathrm{mmol} / \mathrm{L} \mathrm{signifi-}$ cantly augmented insulin release from perfused rat pancreas.

Other authors have demonstrated that several stimuli of insulin secretion caused a breakdown of inositol phospholipids in pancreatic B cells and free inositol was formed (Mathias et al., 1985; Zawalich et al., 1995). It was also observed that lithium-inhibited inositol dephosphorylation led to simultaneous restriction of insulin release (Mathias et al., 1985; Vadakekalam et al., 1996). The inhibition of insulin release by diazoxide, an opener of potassium channels, also limited formation of free inositol (Vadakekalam et al., 1996). Similar results were observed in the absence of extracellular calcium (Vadakekalam et al., 1996). Thus, the cleavage of inositol phospholipids and formation of free inositol seem to be necessary for insulin secretion. On the other hand, inositol is also taken up by pancreatic B cells from the extracellular space (Xia and Laychock, 1993) and inositol phospholipids are formed. This process takes place before stimulation of insulin secretion and subsequent stimulation of hormone release causes increased free inositol generation (Mathias et al., 1985; Zawalich et al., 1995). It was also demonstrated that the inositol content of pancreatic islets may be affected by several factors and was decreased when the rats were fed a diet deprived of this compound (Sener et al., 1992). Thus, it seems possible that inositol contained in the perfusion medium was incorporated into inositol phospholipids and formation of some compounds involved in insulin secretion (for example inositol 1,4,5-trisphosphate and inositol hexaphosphate) was augmented. This may increase the sensitivity of pancreatic B cells to glucose and augment their response to this sugar. It was observed that increased concentration of inositol 1,4,5-trisphosphate and inositol hexaphosphate formed in pancreatic B cells from inositol is an important factor stimulating insulin secretion (Morgan et al., 1985; Efanov et al., 1997). Larson at al. (1997) demonstrated that inositol hexaphosphate increased the activity of voltage-gated calcium channels by inhibition the serine-threonine protein phosphatases in B cells of the pancreas. This elicited an increase of calcium influx over the plasma membrane and caused insulin secretion.

Another possible mechanism of inositol influence on insulin secretion is related to degradation of this compound. Nahapetian and Young (1980) demonstrated that inositol absorbed from the digestive tract may be metabolised in cells and $\mathrm{CO}_{2}$ 
is formed. ATP generated as a result of this process may cause closure of ATP-dependent potassium channels, depolarization of the cell membrane, opening of voltage-gated calcium channels followed by increase of $\mathrm{Ca}^{2 \cdot}$ concentration in the cytosole of B cells, and finally insulin secretion. This mechanism is similar to that proposed for glucose. However, in the case of this sugar, potentiation of hormone release is dose-dependent. Myoinositol augmented insulin secretion only at the concentrations of 1.55 and $15.5 \mathrm{mmol} / \mathrm{L}$ and this effect was similar in the case of both concentrations. These results may suggest that metabolism and/or uptake of inositol in pancreatic B cells is limited.

It can be estimated that, depending on different conditions, myoinositol may be present in blood serum at a concentration of about $0.1-1 \mathrm{mmol} / \mathrm{L}$. The results obtained in this experiment clearly indicate that this compound may be an important food-derived factor which augments insulin secretion in the presence of glucose at physiological concentrations. Increase of glucose-stimulated insulin release by this compound may simultaneously take place by different paths. It seems possible that inositol itself does not directly influence insulin secretion, but rather acts via the formation of other compounds involved in hormone release such as ATP, inositol phospholipids or inositol hexaphosphate. This assumption may be additionally supported by the observation that insulin secretion was not augmented at once after addition of inositol to the perfusion medium and some period of time for inositol metabolism was required. It was also demonstrated that for insulin secretion to rise in response to inositol a relatively high concentration of this compound was required and a further increase of inositol concentration did not produce additional augmentation of insulin release.

\section{REFERENCES}

Andersen D.B., Holub B.J., 1980. Myo-inositol-responsive liver lipid accumulation in the rat. J. Nutr. 110, 488-495

Efanov A.M., Zaitsev S.V., Berggren P.O., 1997. Inositol hexakisphosphate stimulates non-Ca ${ }^{2-}-$ mediated and primers $\mathrm{Ca}^{2+}$-mediated exocytosis of insulin by activation of protein kinase $\mathrm{C}$. Proc. Natl. Acad. Sci. USA 94, 4435-4439

Larsson O., Barker C.J., Sj-oholm A., Carlqvist H., Michell R.H., Bertorello A., Nilsson T., Honkanen R.E., Mayr G.W., Zwiller J., Berggren P.O., 1997. Inhibition of phosphatases and increased $\mathrm{Ca}^{21}$ channel activity by inositol hexakisphosphate. Science $278,471-474$

Mathias P.C.F., Best L., Malaisse W.J., 1985. Stimulation by glucose and carbamylcholine of phospholipase $\mathrm{C}$ in pancreatic islets. Cell. Biochem. Funct. 3. 173-177

Morgan N.G., Rumford G.M., Montague W., 1985. Studies on the role of inositol trisphosphate in the regulation of insulin secretion from isolated rat islets of Langerhans. Biochem. J. 228, 713-718

Nahapetian A., Young V.R., 1980. Metabolism of ${ }^{14}$ C-phytate in rats: effect of low and high dietary calcium intakes. J. Nutr. 110, 1458-1472

Penhos J.C., Wu Ch.H., Basabe J.C., Lopez N., Wolff P.W., 1969. A rat pancreas-small gut preparation for the study of intestinal factors and insulin release. Diabetes $18,733-738$ 
Sakamoto K., Vucenik I., Shamsuddin A.M., 1993. [ $\left.{ }^{3} \mathrm{H}\right]$ Phytic acid (inositol hexaphosphate) is absorbed and distributed to various tissues in rats. J. Nutr. 123, 713-720

Reddy N.R., Sathe S.K., Salunkhe D.K., 1982. Phytates in legumes and cereals. Adv. Food Res. 28, $1-92$

Sener A., Ramirez R., Malaisse W.J., 1992. A sensitive radioisotopic assay of myo-inositol: its application to rat pancreatic islets. Biochem. Med. Metab. Biol. 47, 116-123

Vadakekalam J., Rabaglia M.E., Chen Q-H., Metz S.A., 1996. Role for GTP in glucose-induced phospholipase C activation in pancreatic islets. Amer. J. Physiol. 271, E85-E95

Xia M., Laychock S.G., 1993. Insulin secretion, myo-inositol transport, and $\mathrm{Na}^{+}-\mathrm{K}^{+}$-ATPase in glucose-desensitized rat islets. Diabetes 42, 1392-1400

Zawalich W.S., Zawalich K.C., Kelley G.G., 1995. Effects of short-term culturing on islet phosphoinositide and insulin secretory responses to glucose and carbachol. Acta Diabetol. 32, 158-164

\section{STRESZCZENIE}

\section{Mio-inozytol zwiększa wydzielanie insuliny przez perfundowaną trzustkę szczura}

W celu określenia bezpośredniego wpływu mio-inozytolu na wydzielanie insuliny, trzustki szczura perfundowano medium zawierającym glukozę $(6,6 \mathrm{mmol} / \mathrm{L})$ lub glukozę z dodatkiem mio-inozytolu w stężeniu 0,$15 ; 1,55$ lub $15,5 \mathrm{mmol} / \mathrm{L}$. Mio-inozytol w najmniejszym stężeniu nie miał wpływu na wydzielanie insuliny, natomiast w stężeniu 1,55 i $15,5 \mathrm{mmol} / \mathrm{L}$ w sposób istotny zwiększył sekrecję insuliny. Całkowita ilość insuliny wydzielona podczas perfuzji z tym związkiem wynosiła odpowiednio 508 i $478 \mu \mathrm{U}$ w porównaniu z $353 \mu \mathrm{U}$ wydzielonych w tym samym okresie perfuzji bez inozytolu. Wydaje się bardzo prawdopodobne, że inozytol może nasilać sekrecję insuliny poprzez tworzenie ATP, fosfolipodów inozytolowych lub sześciofosforanu inozytolu. 